\title{
Accelerate disaster risk mapping using an automated zonal change detection model for loss estimation and recovery: a flood case study
}

Ali Amasha(D)

\begin{abstract}
Background: The flash flood still constitutes one of the major natural meteorological disasters harmfully threatening local communities, that creates life losses and destroying infrastructures. The severity and magnitude of disasters always reflected from the size of impacts. Most of the conventional research models related to flooding vulnerability are focusing on hydro-meteorological and morphometric measurements. It, however, requires quick estimate of the flood losses and assess the severity using reliable information. An automated zonal change detection model applied, using two high-resolution satellite images dated 2009 and 2011 coupled with LU/LC GIS layer, on western El-Arish City, downstream of Wadi El-Arish basin. The model enabled to estimate the severity of a past flood incident in 2010.
\end{abstract}

Results: The model calculated the total changes based on the before and after satellite images based on pixel-bypixel comparison. The estimated direct-damages nearly 32,951 $\mathrm{m}^{2}$ of the total mapped LU/LC classes; (e.g., 11,407 $\mathrm{m}^{2}$ as $3.17 \%$ of the cultivated lands; $6031 \mathrm{~m}^{2}$ as $7.22 \%$ of the built-up areas and $4040 \mathrm{~m}^{2}$ as $3.62 \%$ of the paved roads network). The estimated cost of losses, in 2010 economic prices for the selected three LU/LC classes, is nearly 25 million USD, for the cultivation fruits and olives trees, $\sim 4$ million USD for built-up areas and $\sim 1$ million USD for paved roads network.

Conclusion: The disasters' damage and loss estimation process takes many detailed data, longtime, and costed as well. The applied model accelerates the disaster risk mapping that provides an informative support for loss estimation. Therefore, decision-makers and professionals need to apply this model for quick the disaster risks management and recovery.

Keywords: Natural hazards, Floods, GIS, Remote sensing, Zonal change detection, Damage and loss estimation

\section{Background}

The severe flash flood hazard is often defined as an existence of water in the commonly dry wadies/channels regardless of the specific discharge or stage [1-3]. Floods are a weather hazard produced by extreme precipitation events in a short time duration [4], affecting a limited area and occur when water flows into a region faster

Correspondence: aliamasha@gmail.com; ali.amasha@aast.edu

Arab Academy for Science, Technology and Maritime Transport (AASTMT), Cairo Campus, Egypt

\section{Springer Open}

(c) The Author(s). 2020 Open Access This article is licensed under a Creative Commons Attribution 4.0 International License, which permits use, sharing, adaptation, distribution and reproduction in any medium or format, as long as you give appropriate credit to the original author(s) and the source, provide a link to the Creative Commons licence, and indicate if changes were made. The images or other third party material in this article are included in the article's Creative Commons licence, unless indicated otherwise in a credit line to the material. If material is not included in the article's Creative Commons licence and your intended use is not permitted by statutory regulation or exceeds the permitted use, you will need to obtain permission directly from the copyright holder. To view a copy of this licence, visit http://creativecommons.org/licenses/by/4.0/. 
Although Egypt is considered as an arid to semi-arid environment, the rainfall occurs only in winter season and located in scattered areas. The historical rainfall records indicated that there was severe flash flood events scattered in many regions in Egypt. This includes Upper Egypt, Sinai, and Red Sea areas that happened in 1976, 1982, 1984, 1994, 1995, and 2010 [9-11];. The average amount of the rainwater falls over Egypt is about $1.3 \mathrm{BCM}$ /year in the rainy seasons [12];. However, the latest rainy storm that hit Egypt on 12-14 March 2020, had fallen amount of rainwater about $0.5 \mathrm{BCM}$ in 3 days, as the prime minister reported, which created sever flood crisis.

North Sinai is the most northern governorate in Egypt and always suffers from flash floods due to the highintensity of rainfalls, which came from the high southern Sinai Mountains [13]. A severe and destructive flash flood has hit El-Arish City downstream Wadi El-Arish, North Sinai, and Gulf of Suez margins to the western Sinai during 17th and 18th of January 2010. This flood has left significant losses of lives and damage to vegetated areas, built-up areas, and road network [14].

Unfortunately, most of the flood literatures in Egypt have not much paid attention to the analysis of the risk and losses of damage. They traditionally demonstrate the hydrographic analysis and flash floods using satellite images and GIS to investigate various aspects of drainage morphometric and its hazards' impacts [15-19]. Furthermore, [20] studied the January's 2010 flood that hit Northern Sinai from the perspective of spatial understanding of storm rain characteristics and drainage basin response using the GIS and satellite datasets. The rainfall storms on Sinai (January 2010 and March 2014) studied by determination of the hydrologic parameters and variables of both basins as well as the analysis of rainfall data for catchment modeling [21]. On the other hand, the vulnerability analysis of the land cover features of El-Arish City and Wadi El-Arish based on an integrated hydro-climatic and physical vulnerability component studied by [22].

In this context, flood loss assessment [23-27] has used the GIS and remote sensing modeling to delineate the flood inundated areas and losses estimation. On the other hand, some researchers have been applied an integrated GIS and hydraulic model as an attempt of real-time damage estimation based on the amount and duration of rains, the flood depth, and the soil physical parameters [20-22, 27]; . The flood warning system in arid regions through an index, termed Alluvial wadi Flood Incipient Geomorphologic Index (AFIG) based on the drainage basin characteristics such as lithology, topography, and precipitation have been studied by [28]. The shortcomings of these studies are the lack of linkage with the estimation of the real impact and losses of LU/LC.

The average annual precipitation of Wadi El-Arish is about $100.7 \mathrm{~mm}$ as reported in [29]. In this context, [20] had compiled a historical data of the recorded flash floods events in Wadi El-Arish after [30-33]. Therefore, the most severe flood events especially which exceed the storage capacity of the El-Rawaffa Dam is listed in (Table 1).

Normally, the disaster risk and loss assessment process requires detailed parameters and takes longtime. The overall objective of this study is to provide an informative and quick methodological framework of disaster risk mapping as a preliminary decision support information for loss estimation and recovery plans. Therefore, a robust methodological framework of an automated change detection model is developed to map the disasters' risks and to estimate the damage losses of the major LU/LC assets, after the 2010 flood incident in Wadi ElArish/El-Arish City, Northern Sinai-Egypt.

\section{Methods}

\subsection{The area of study}

Wadi El-Arish basin considered as the largest dry wadi in Sinai Peninsula, Egypt. It flows from the Southern Sinai plateaus through its narrow downstream passing northwards through El-Arish City and ends at the Mediterranean Sea. Its catchment area covers about $21,700 \mathrm{~km}^{2}$, which constitutes about 36\% of the total area of Sinai [22]. However, it is a dry basin, in some cases with high intensity of precipitation it creates severe flooding event.

Because of the dominant LU/LC within the study area such agriculture, urban, and industrial activities have threatened by infrequent flash floods [34]. Therefore, the Egyptian government had constructed El-Rawaffa Dam, $50 \mathrm{~km}$ southern to El-Arish city in 1946 to store $3 \times 10^{6}$ $\mathrm{m}^{3}$, to minimize the flood risks [30]. The dam had reconstructed in 1987 to increase its storage capacity to $5.5 \times 10^{6} \mathrm{~m}^{3}$. Nevertheless, the city was prone to several flash floods of different magnitudes.

The area of study is located in the Northern Sinai, the north most of wadi El-Arish (western of El-Arish city), Egypt, between Eastings 576591 to 577694, and Northings 3442644 to 3446248 (in UTM Projection system), and measured about $4 \mathrm{~km}^{2}$ (Fig. 1).

\subsection{Satellite and GIS datasets}

Two high-resolution satellite images, before and after the flooding event, are obtained. The before satellite image that from Geoeye sensor dated 24 September 2009 is processed to categorize the existing land use/land cover (LU/LC), and the after satellite image is from Worldview2 sensor dated 27 March 2011. Both images have spatial resolution of $50 \mathrm{~cm}$ for accuracy pixel-by-pixel comparison. Both images are compatible in multispectral channels that eased the comparison. The two satellite images are trimmed to the actual area of study and spatially analyzed 
Table 1 The most severe flash flood events occurred from 1947 to 2010 after [20]

\begin{tabular}{|c|c|c|c|}
\hline Severe flood events & $\begin{array}{l}\text { Precipitation } \\
\left(10^{6} \mathrm{~m}^{3}\right)\end{array}$ & $\begin{array}{l}\text { El-Rawaffa Dam capacity } \\
\left(10^{6} \mathrm{~m}^{3}\right)\end{array}$ & $\begin{array}{l}\text { Invaded amount } \\
\left(10^{6} \mathrm{~m}^{3}\right)\end{array}$ \\
\hline March, 1947 & 21 & 3 & 18 \\
\hline 1950 & 18 & 3 & 15 \\
\hline 27th March, 1965 & 30 & 3 & 27 \\
\hline 19 February 1975 & 120 & 3 & 117 \\
\hline 1979 & 30 & 3 & 27 \\
\hline 18 January 2010 & 124 & 5.5 & 118.5 \\
\hline
\end{tabular}

based on the LU/LC zones (i.e., GIS layer) to map the disaster flood risk (Fig. 2).

\subsection{Data processing and modeling}

Initially, the satellite images have enhanced and geographically corrected to UTM Projection system, Zone 36N, Spheroid and Datum WGS 1984. Then, a GIS layer of the existing (LU/LC) features has extracted from the before image for further spatial analysis (e.g., area extraction and other overlay functions).

The zonal change detection model is applied to compute the zonal changes between the two satellite images based on pixel-by-pixel comparison model. The attributes of "area change" and "percent change" is automatically generated based on the identified LU/LC categories in the GIS zones. The logical framework of the zonal change detection model and processing steps is simplified in (Fig. 3).

The algorithm used in the zonal change detection model is shown in Eq. (1) [35].

$$
\frac{T 2-T 1}{|T 1|}+\frac{T 2-T 1}{|T 2|}
$$

It estimates the difference between the two satellite images at time 1 (T1) and time 2 (T2), which allows the derivation of any changes between the two dates. It generates a new image with the changes between the two dates (i.e., before and after images), that estimates the

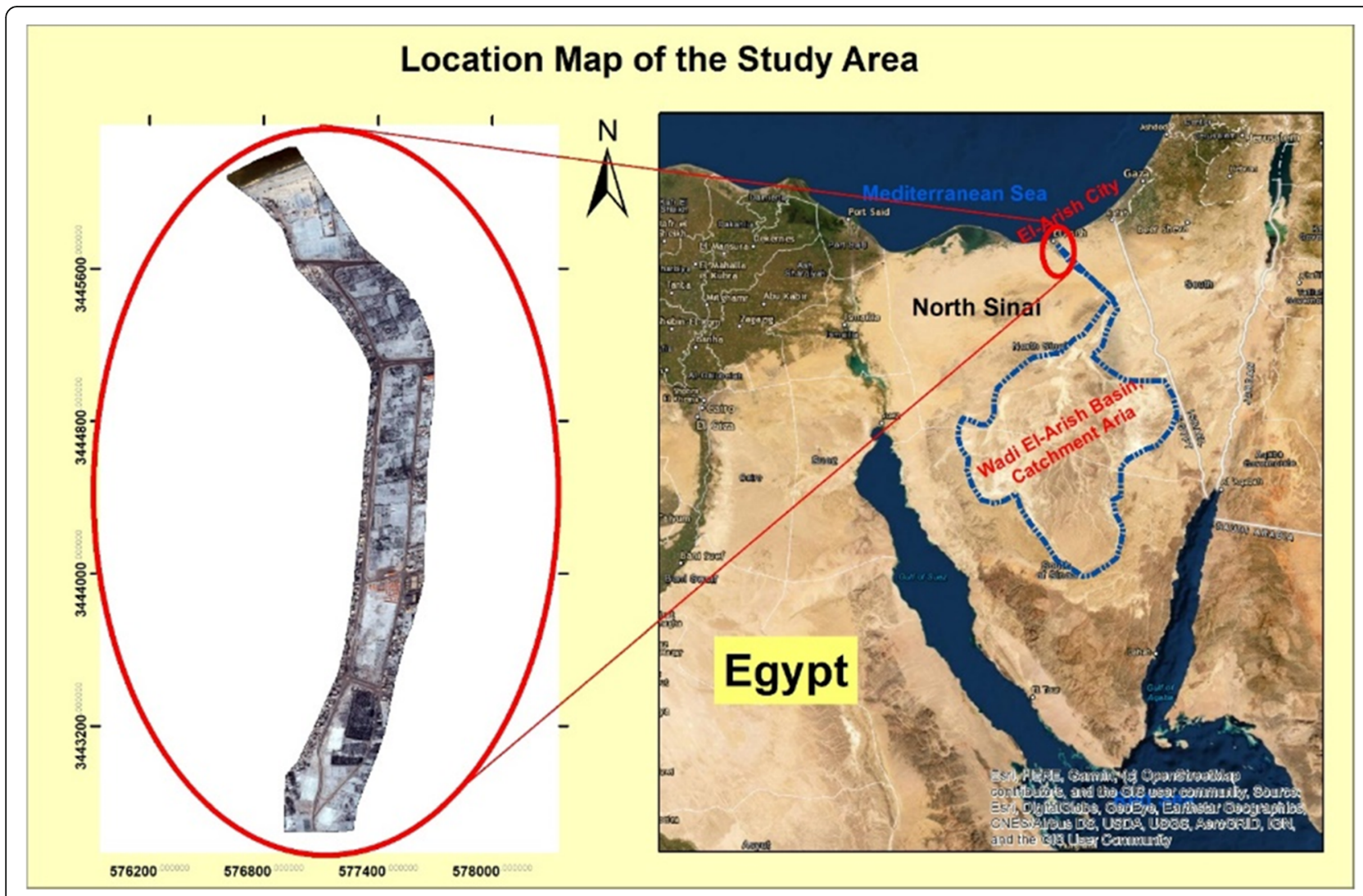

Fig. 1 Geographical location of the area of study 


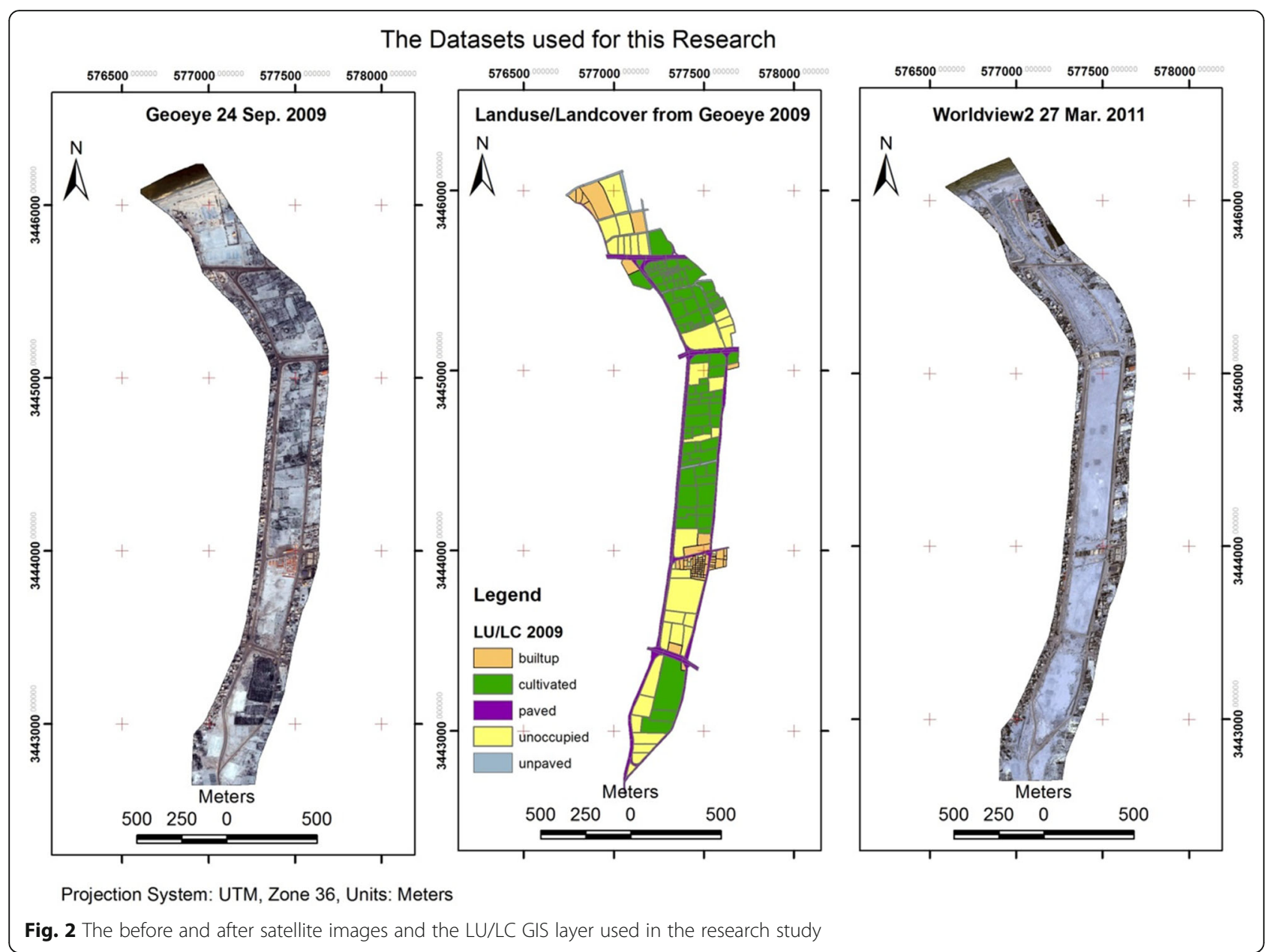

percentage of change at the smallest pixel size $(0.5 \mathrm{~m})$. In most cases, the higher percentage of change is indicated by higher brightness [35].

The result of a digital image change detection process is largely controlled by the quality of geographic correction and overall the quality of used images. Hence, it is essential to verify the output change image against the original satellite data input. This verification is done based on polygon-by-polygon comparison as changed or no changed which is stored in a GIS shapefile as the area of change and the percent of changes.

\section{Results and analysis}

Five major land use and land cover categories are mapped from the high-resolution satellite image Geoeye dated 2009, which are built-up areas, agriculture land, paved and unpaved roads, and unoccupied lands. These five categories are occupying nearly 212 acres $\left(857,725 \mathrm{~m}^{2}\right)$, (Fig. 2) and (Table 2). Due to a miss planning of the study area, there were valued LU/LC assets like urbanization located downstream at the low topography land of the valley, which is the first vulnerable to flood risk. The second vulnerable
LU/LC class is the agriculture lands, which normally dominant within the fertile land of the wadi and based on the reserved ground water from the run off. The third vulnerable class is the road networks within the affected area. The last two classes are not valued to be considered in the lose estimation (e.g., unpaved roads and unoccupied land). The identified changes between the two satellite images (before and after) with their percentage and area of changes in each LU/LC category are shown in Fig. 4 and Table 2.

The model calculated the changes of the analyzed area at $32,951 \mathrm{~m}^{2}$ that has damaged. The detailed spatial analysis of these changes in areas and percentages of the five major mapped LU/LC categories has discussed as follow as shown in Fig. 5 and Table 2.

- The urbanized areas have distributed along 74 zones in the model that covers $83,509 \mathrm{~m}^{2}$ (nearly $10 \%$ of the total processed area). The calculated changes of this category measured by $6031 \mathrm{~m}^{2}$ (i.e., $7.22 \%$ of the mapped built-up area).

- The agriculture and cultivated land is the largest category, which occupied nearly $42 \%\left(359,825 \mathrm{~m}^{2}\right)$ 


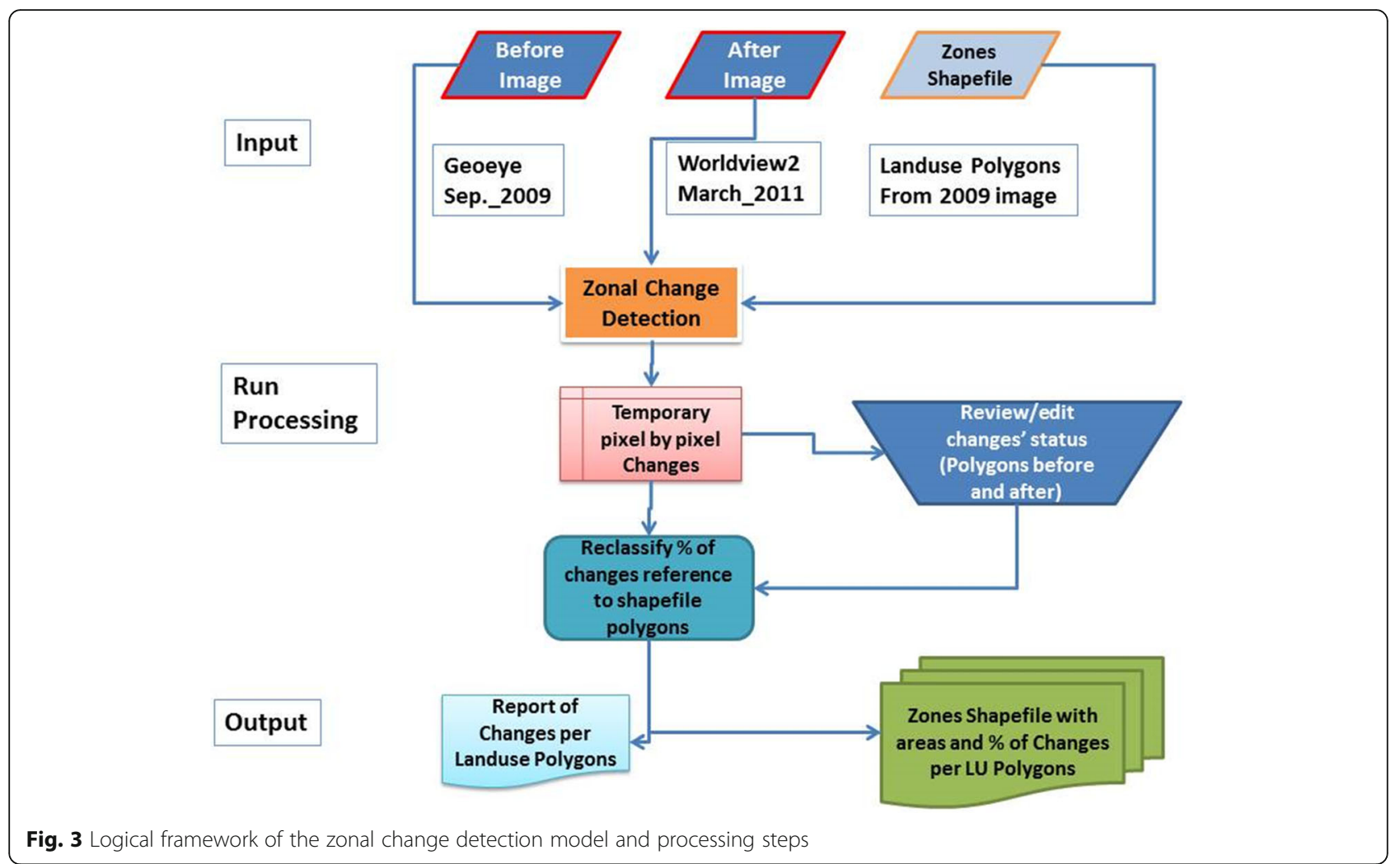

of the total processed area. This category has distributed along 104 zones that subjected to major changes, which calculated as $11,407 \mathrm{~m}^{2}$ (i.e., $3.17 \%$ of the mapped cultivated lands) were lost.

- The area of the paved and well-structured road networks within the area of study is calculated by $111,448 \mathrm{~m}^{2}$ (nearly $13 \%$ of the total processed area). The calculated damage of this category is $4040 \mathrm{~m}^{2}$ (i.e., 3.62\% of the paved roads' area).

- The area of the unpaved road that serve most of the local Bedouin inhabitants estimated by $19,546 \mathrm{~m}^{2}$ (2.28\% of the total processed area). Unfortunately, there were $2157 \mathrm{~m}^{2}$ (i.e., $11 \%$ of the unpaved tracks' area) had altered.

- The unoccupied and free land category, which identified as the changes of texture and pattern between the two processed images, even it was still unoccupied. So, it should not be considered as disaster losses unless it includes the debris and rubbish due to the flash flood that might need to clean-up.

Where

- The (area) is calculated from the LU/LC classes dated 2009 (extracted from the before satellite image). The total area sums at $857,725 \mathrm{~m}^{2}$.

- (Area\%) is calculated by each LU/LC Type (i.e., area/total LU/LC area "857,725") × 100).

- The (changed area) is calculated from the zonal change detection analysis for each changed LU/LC class, which sums at $32,951 \mathrm{~m}^{2}$.

- (Change \%) is calculated for each changed class in reference to its original area (i.e., changed area/its LU/LC type area) $\times 100$ ). The changed percentages calculated in relative to each individual LU/LC area;

Table 2 Summary of the LU/LC areas of change and their percentages

\begin{tabular}{llllll}
\hline LU/LC type & \# Model zones & Area $\left(\mathbf{m}^{\mathbf{2}}\right)$ & Area \% & Changed area $\left(\mathbf{m}^{\mathbf{2}}\right)$ & Change $\%$ \\
\hline Urbanized areas & 74 & 83,509 & 9.74 & 6031 & 7.22 \\
Cultivated & 104 & 359,825 & 41.95 & 11,407 & 3.17 \\
Paved & 101 & 111,448 & 12.99 & 4040 & 3.62 \\
Unoccupied & 37 & 283,398 & 33.04 & 9316 & 3.29 \\
Unpaved & 23 & 19,546 & 2.28 & 2157 & 11.04 \\
Total & & $\mathbf{8 5 7 , 7 2 5}$ & $\mathbf{1 0 0}$ & $\mathbf{3 2 , 9 5 1}$ & $\mathbf{Z}$ \\
\hline
\end{tabular}




\section{Zonal Change Detection: Percent of Changes Classification}

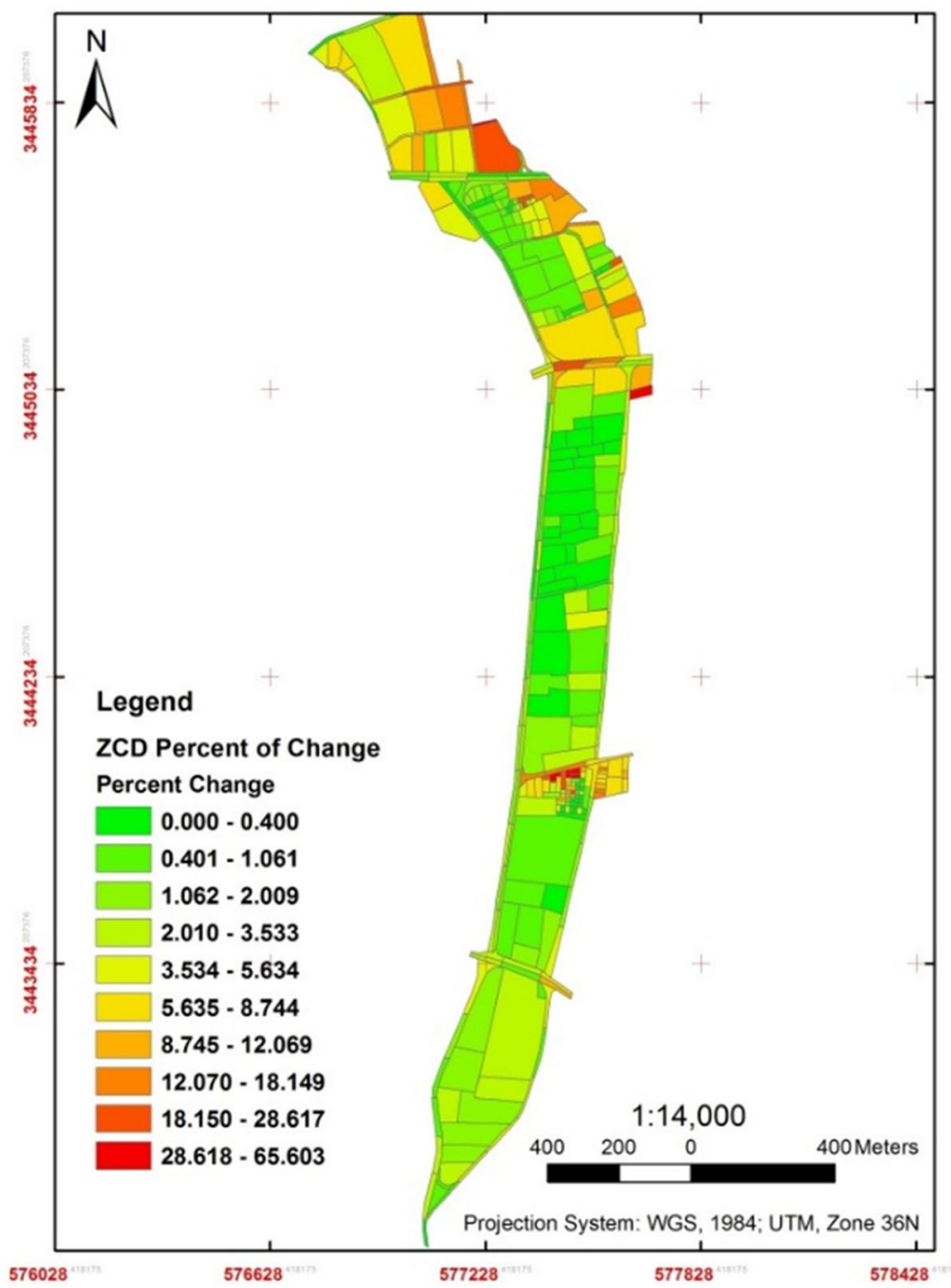

Fig. 4 The changes between the before and after images as a result from the zonal change detection model

however, it sums at $3.84 \%$ of the total analyzed area $\left(857,725 \mathrm{~m}^{2}\right)$.

\section{Discussion}

In some developing countries, and due to the flooding has not frequently happened, the assessment of economic losses is out of scope. The quick preliminary estimation of the damage losses might alert the government to develop mitigation strategy that minimize the risk and reduce the losses further. The main approach, in this research, is to show off the hazard, risk, and losses estimation due to an extreme flood event. Therefore, it is necessary to identify and map the changes of the existing economically valued land use and land cover features before and after the flood event.

The flood damage normally categorized into two main types: (1) tangible, which includes direct and indirect damages that mainly refer to quantitative analysis, and (2) intangible damage, which is refer to a qualitative analysis. Both direct and indirect damage of the tangible are reflecting the losses or disability to access the area under flooding due to cut-off of facilities or/and infrastructure. Therefore, the consequences are large economic losses. Table 3 lists the damage of buildings and their contents; disruption of infrastructure such as roads, railroads, erosion of agricultural soil, destruction of harvest, damage to live-stock, evacuation, and rescue measures; business interruption inside the flooded area and cleanup costs.

In the context of the 2010 flood event under this study, it is reported that the water level reached about 2 $\mathrm{m}$ above the ground level. It created 6 death cases and many injured people, in addition to many missing people. Moreover, about 600 houses are completely devastated and nearly 1500 houses are partially damaged in 


\section{Zonal Change Detection Percent of Area Changes}

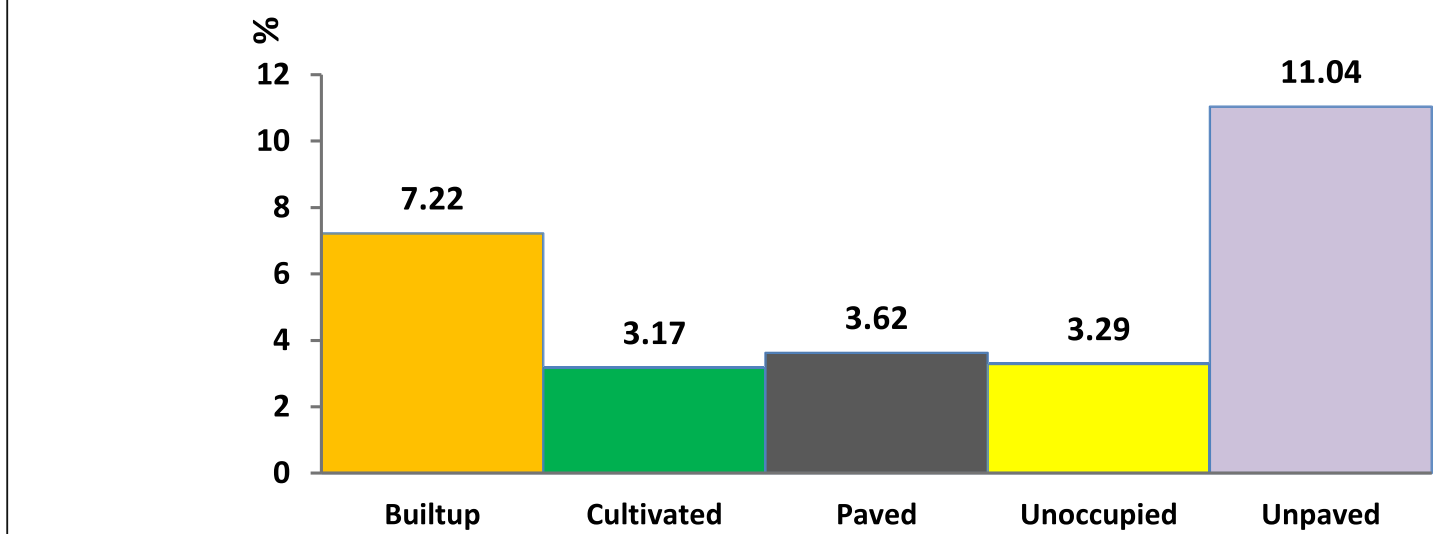

Fig. 5 Percentages of changes of the five LU/LC classes after the flash flood event

addition to the wash-up of many trees and cars with significant damage in the infrastructures (roads, electricity, potable water lines, etc.) [20].

The disaster damage and loss assessment process requires detailed information about the land-use activities to quantify the precise losses. Such detailed information takes long time to collect and sophisticated model to process. This research study proposes a robust model to estimate the losses and identify the tangible-direct-primary damages for each of the major pre-identified LU/LC categories. In developing countries, there is a lack to develop comprehensive database about human settlements and their households such missing information make it difficult for the model to quantify the indirect-secondary and intangible damage. Therefore, the model is easily quantified the damage and loss for the economically valued classes of agriculture and cultivated lands, urbanized areas, and paved roads, which constitutes $21,478 \mathrm{~m}^{2}$ (nearly 14\% of the total changed area) (Table 2). The other two less-valued classes (unpaved tracks/roads and unoccupied areas) are excluded due to the difficulty to estimate their unit cost.

The economic damage and losses is estimated based on the common local unit price and cost in 2010 (Table 4).
Field survey and observation is essential to improve the classification and categorization of the land use and land cover classes. Unfortunately, due to the limitation of accessibility to the study area, in Sinai, to obtain in-situ field verification of the LU/LC classes. Hence, the accuracy of the produced results is depended on the accuracy of the visual interpretation of the satellite image. Then, the value of this model is to use high-resolution satellite images (e.g., $0.5 \mathrm{~m}$ pixel size) that enable for precise quantification of the losses and damages. Such, integration of high spatial resolution and robust model provide decision-makers and professionals with more accurate information for the LU/ LC that support for preliminary and quick response to the community with a mitigation and rescue plans.

The model is generic to compute the damaged classes and the economic value of these classes, which depend on the accurate computation of the types and ages of cultivation (e.g., fruit and palm trees, croplands, vineyards), the age of the building, its characteristics (e.g., fabric types, rural or urban, furniture), the domestic animals, and some different assets in the study area. The availability of these detailed information would ensure more accurate and precise model for economic losses calculation. It is, however, still valid to be applied for any information and the accuracy depends on the accuracy of input information.

Table 3 Flood damages categories and loss examples [36]

\begin{tabular}{|c|c|c|c|}
\hline \multicolumn{3}{|l|}{ Category } & \multirow{2}{*}{$\begin{array}{l}\text { Description of loses } \\
\text { Structures, contents, and agriculture }\end{array}$} \\
\hline Tangible & Direct & Primary & \\
\hline & & Secondary & Land and environment recovery \\
\hline & Indirect & Primary & Business interruption \\
\hline & & Secondary & Impact on regional and national economy \\
\hline \multicolumn{3}{|l|}{ Intangible } & Health, psychological damage \\
\hline
\end{tabular}


Table 4 The estimated economic cost of the damaged and losses of the valued classes

\begin{tabular}{|c|c|c|c|}
\hline LU/LC & $\begin{array}{l}\text { Damaged } \\
\text { area }\left(\mathrm{m}^{2}\right)\end{array}$ & $\begin{array}{l}\text { Unit price } \\
\left(\$ \cup S / m^{2}\right)\end{array}$ & $\begin{array}{l}\text { Total loss cost } \\
\left(\$ \mathrm{US} / \mathrm{m}^{2}\right)\end{array}$ \\
\hline Agriculture/cultivated & 11,407 & 2272.7 & (Fruit trees) $\quad 25,925,000$ \\
\hline Urbanized areas & 6031 & 545.45 & $3,289,500$ \\
\hline Paved roads & 4040 & 181.8 & 734,455 \\
\hline Total area & 21,477 & - & $29,948,955$ \\
\hline
\end{tabular}

\section{Conclusion}

In conclusion, assessment of flood damages is a fundamental step for the disaster risk reduction and recovery demands in order to develop mitigation procedures. Nowadays, the assessment of flood damage is gaining a specific interest as flood risk management, which becoming the dominant approach of flood control policies. This research study introduced a model that is showing a case to support decision-makers for informative information about flood damage and economic losses. The use of high-resolution satellite images in the before and after of the flood event enables to estimate the changes in the land use and land cover precisely. Therefore, the model enabled to estimate robustly the damage and economic losses based on the local market unit price of the most common features in the areas of study. In this case, the urbanization, agriculture, and roads are affected with nearly 30 million USD losses. The increased level of accuracy of the data used in the model will improve the accuracy of estimation of the economic losses. Finally, the zonal change detection model is used to highlight quickly the changes after either the flood or any other disaster events that left damages behind. Indeed, this will be supportive to decision makers to estimate damage and losses, introduce recovery plans of the damaged areas and disaster risk reduction's strategies as well.

\section{Abbreviations}

GIS: Geographic information system; LU/LC: Classes of Landuse/landcover mapping that identified from the satellite images; UTM: Universal transverse mercator is a world system of map projection

\section{Acknowledgements}

The author acknowledges Edge-Pro Co., Egypt, for their providing the raw satellite images and their technical support.

\section{Author's contributions}

The author declares that he is the single author of this manuscript. The author read and approved the final manuscript.

\section{Funding}

This research received no external funding.

\section{Availability of data and materials}

The datasets used and/or analyzed during the current study are available from the corresponding author on reasonable request.

Ethics approval and consent to participate

Not applicable.
Consent for publication

Not applicable.

\section{Competing interests}

The author declares no competing interests.

Received: 4 September 2020 Accepted: 22 October 2020

Published online: 11 November 2020

\section{References}

1. Graf WL (1988) Fluvial Processes in Dryland Rivers. Springer Series in Physical Environment, Springer Verlag, 1988th edition, p 346

2. Cooke RU, Warren A, Goudie AS (1993) Desert Geomorphology. University College London Press, London

3. Tooth S (2000) Process, form and change in dryland rivers: a review of recent research. Earth Sci Rev 51:67-107

4. Moawad MB, Aziz AOA, Mamtimin B (2016) Flash floods in the Sahara: a case study for the 28 January 2013 flood in Qena, Egypt. Geomat Nat Hazards Risk 7(1):215-236 https://doi.org/10.1080/19475705.2014.88546 7

5. Schick AP, Sharon D (1974) Geomorphology and climatology of arid watersheds. Department of Geography, Hebrew University, Jerusalem, p 153

6. Elmoustafa, A.M.; Mohamed, M.M. (2013a)"Flash flood risk assessment using morphological parameters in Sinai Peninsula. Open J Mod Hydrol, 3:122129. https://doi.org/10.4236/ojmh.2013.33016

7. Wheather, H.S. "Hydrological processes in arid and semi-arid areas.(2002) " International Hydrological Programme, IHP-V, Technical Documents in Hydrology, No. 55, UNESCO, Pari.

8. Niyongabire E, Hassan R, Elhassan E, Mehdi M (2016) Use of digital elevation model in a GIS for flood susceptibility mapping: case of Bujumbura City. In: Proceedings, 6th international conference on cartography and GIS. Albena, Bulgaria, pp 241-248

9. El-Rakaiby ML (1989) Drainage basins and flash flood hazard in selected parts of Egypt. Egypt J Geol 33:307-323

10. El-Shamy IZ (1992) Recent recharge and flash flooding opportunities in the Eastern Desert, Egypt. Ann Geol Surv Egypt 18:323-333

11. El-Bastawesy M, Habeebullah T, Balkhair K, Ascoura I (2013) Modelling flash floods in arid urbanized area: Makkah (Saudi Arabia). Secheresse 24:1-11

12. Ebaid H, M.; Farag, Hanan.A.; El Falaky, Asia. A. (2016) Using GIS and Remote Sensing Approaches to Delineate Potential Areas for Runoff Management Applications in Egypt. Inter J Env Sci Eng 7:85-93

13. Farahat MS, Elmoustafa AM, Hasan AA (2017) Developing flash floods inundation maps using remote sensing data, a case study: Wadi AL-Arish, Sinai, Egypt. Am J Eng Res (AJER) 6(5):172-181

14. Gabr S, El-Bastawesy M (2015) Estimating the flash flood quantitative parameters affecting the oil-fields infrastructures in Ras Sudr, Sinai, Egypt, during the January 2010 event. Egypt J Remote Sens Sp Sci 18:137-149

15. Abduladheem A, Elmewafey M, Beshr AF, Elnaggar AA (2015) "Using GIS based morphometry estimation of flood hazard impacts on desert roads in South Sinai" Egypt. Int J Sci Eng Res 6(7):1593-1599

16. Elkhrachy, I."Flash flood hazard mapping using satellite images and GIS tools: a case study of Najran City, Kingdom of Saudi Arabia (KSA)." Egypt J Remote Sens Sp Sci, 2015; 18(2):261-278. https://doi.org/10.1016/j.ejrs.2015. 06.007

17. Gianinetto, M.; Villa, P.; Lechi, G. (2006) "Post-flood damage evaluation using Landsat TM and ETM+ data integrated with DEM." IEEE Trans Geosci Remote Sens 44(1):236-243. https://doi.org/10.1109/TGRS.2005.859952

18. Ghani AB, Ali R, Zakaria NA, Abu Hasan ZA, Chang CK, Ahmad SSM (2010) A temporal change study of the Muda River System over 22 years. Int J River Basin Manag 8(1):25-37

19. Haq, M.; Akhtar, M.; Muhammad, S.; Paras, S.; Rahmatullah, J. (2012) "Techniques of remote sensing and GIS for flood monitoring and damage assessment: a case study of Sindh province, Pakistan." Egypt J Remote Sens Sp Sci; 15(2):135-141. https://doi.org/10.1016/j.ejrs.2012.07.002

20. Moawad, M.B. (2013) "Analysis of the flash flood occurred on 18 January 2010 in wadi El Arish, Egypt (a case study)." Geomatics Nat Hazards Risk; Vol. 4, No. 3, https://doi.org/10.1080/25427419475705.2012.731657

21. Morad N (2016) Assessment of The Rainfall Storm Events of January 2010 And March 2014 for The Catchment Modeling of Wadi El Arish and Wadi Wardan Basins, Sinai, Egypt. Egyptian J Desert Res. 66(1):137-168

22. Mohamed, Soha A. and El-Raey, M.E. (2019) "Vulnerability assessment for flash floods using GIS spatial modeling and remotely sensed data in El-Arish 
City, North Sinai, Egypt." Nat Hazards; https://doi.org/10.1007/s11069-01903571-x

23. Yamagata Y, Akiyama T (1988) Flood damage analysis using multi-temporal landsat thematic mapper data. Int J Remote Sensing 9:503-514

24. Shaw P (1994) Use of remote sensing and GIS in the economic analysis of flood damage reduction: three recent case histories. Resour Water Manage 23:213-218

25. Consuegra D, Joerin F, Vitalini F (1995) Flood Delineation and Impact Assessment in Agricultural Land Using GIS Technology, Geographical Information Systems in Assessing Natural Hazards. Kluwer Academic Publishers, Netherlands, pp 177-198

26. Lanza L, Siccardi F (1995) The role of GIS as a tool for the assessment of flood hazard at the regional scale. Geogr Inf Syst Assessing Nat Hazards 11: 199-217

27. Jonge TD, Matthiis K, Hogeweg M (1996) Modeling Floods and Damage Assessment Using GIS. HydroGIS 96: Application of Geographic Information Systems in Hydrology and Water Resources Management (Proceedings of the Vienna Conference, April 1996). IAHS Publ. no. 235, pp 299-306

28. Shamir, E.; Ben-Moshe, L.; Ronen, A.; Grodek, T.; Enzel, Y.; Georgakakos, K.P.; Morin, E. (2013) "Geomorphology-based index for detecting minimal flood stages in arid alluvial streams." Hydrol Earth Syst Sci; 17:1021-1034. https:// doi.org/10.5194/hess-17-1021-2013.

29. The World Bank "Climate baseline. Egypt dashboard." (2013) http://sdweb x. world bank.org/climate portal/index .cfm?page=count ry_histo rical _clima te\&ThisR egion =Afric a\&This C Code=EGY

30. Botrous KG (1960) Water resources in Sinai Peninsula. In: In Encyclopedia of Sinai (in Arabic), Supreme Council of Sciences. Al Amiria Press, Cairo, pp 214-227

31. Dames and Moore International (1985) Sinai Data Book: Sinai Development Study. Phase I, Final report, vol VII. the Advisory Committee for Reconstruction Ministry of Development, Cairo

32. Khidr MM (1997) The main geomorphological hazards in Egypt (in Arabic). M.Sc. thesis, Department of Geography, Faculty of Arts, Ain Shams University, Cairo, Egypt, p 513

33. Klein M (2000) The formation and disappearance of a delta at the El-Arish river mouth. In: In Proceedings of the Jerusalem Conference, May 1999, Jerusalem, vol 261. IAHS Publ, Jerusalem, pp 303-310

34. El-Bihery MA, Lachmar E (1994) Groundwater quality degradation as a result of overpumping in the delta wadi El-Arish area, Sinai Peninsula, Egypt. Environ Geol 24:293-305

35. ERDAS Imagine S/W Package, Ver 2015 Usere's Guide

36. Merz, B.; Kreibich, H.; Schwarze, R.; Thicken, A. (2010) "Assessment of economic flood damage." Nat Hazards Earth Syst Scil; 10:1697-1724. https:// doi.org/10.5194/nhess-10-1697-2010.

\section{Publisher's Note}

Springer Nature remains neutral with regard to jurisdictional claims in published maps and institutional affiliations.

\section{Submit your manuscript to a SpringerOpen ${ }^{\circ}$ journal and benefit from:}

- Convenient online submission

- Rigorous peer review

- Open access: articles freely available online

- High visibility within the field

- Retaining the copyright to your article

Submit your next manuscript at $\boldsymbol{\nabla}$ springeropen.com 